\title{
Combustion Characteristics of Diffusion Flame by Swirling Fuel Flow
}

\author{
○学 古里 拓也（鹿児島大院） 正 井手 英夫（鹿児島大） \\ 正 矢野 利明（鹿児島大）伊東 克郎 （鹿児島大）
}

Takuya FURUSATO, Hideo IDE, Toshiaki YANO, Katsurou ITO

Kagoshima University, 1-21-40, Korimoto, Kagoshima, Japan

Key Words : Combustion,Swirling Flow,Diffusion Flame

\section{1. まえがき}

火炎の安定燃焼は、燃焼器の信頼性と安全性を確保する上 で，きわめて重要な技術である，そして，保炎性能の向上や 新しい保炎方法の開発に際し, 保炎機構の解明が重要となる (1). 保炎方法のひとつに，同軸二重円管を用いて環状部から 燃料を供給するブラストバーナー(2)がある.

ブラストバーナ一の燃焼状態は, 燃料と酸化剤の流速のバ ランスによる混合状態で決まる. 混合の割合によっては火炎 長が非常に長くなったり，燃焼状態が不安定になったりする. 燃焼器のコンパクト化と安定化という見地では改善を要する 点である。

本研究で使用するバーナーは，火炎長の短縮化と保炎性能 の向上を目的として, 然料と酸化剂をより混合させるために 燃料流に旋回を与えている，旋回流には流体の混合を促進す る働きがあり，多種多様な装置や機器に取り入れられている (3).

本研究においては，ディジタルビデオカメラによる火炎の 直接画像の撮影と, 熱電対を用いた温度分布測定から主に火 炎基部の構造を解析し, その燃焼特性を解明した。さらに, 従来のブラストバーナーと本研究で得られた火炎長さと浮き 上がり高さを比較し，バーナ一の性能改善について検討した ことを述べている.

Di：ノズル外管内径

\section{2. 記号}

Do：ノズル外管外径

di : ノズル内管内径

do : ノズル内管外径

Nh：絞り部端からのノズル長さ

$\mathrm{Q}$ : 流量

A : 環状部断面積

$V$ : 燃料流平均流速

Re : レイノルズ数

$\mathrm{Dh}:$ 相当直径

$v$ :プロパンの動粘性保数

Fh : 火炎全長

Lh : 火炎の浮き上がり高さ
流となった燃料流は絞り部を通過しノズルから噴出する.

火炎形状は，ディジタルビデオカメラで火炎側面から火炎 全体と火炎基部を撮影し，データをパソコンに取り込み， 1 コマ $1 / 30[\mathrm{sec}] こ ゙ と の$ 画像から火炎長さ・浮き上がり高さを計 測した. 火炎の温度分布は $\mathrm{R}$ 型熱電対を用い, 温度測定記録 装置であるキーエンス社の NR-1000を通じてパソコンに測定 結果を記録した，温度測定の範囲はノズルが軸対称であるの で, 半径方向はノズル中心から $20[\mathrm{~mm}]$, 軸方向は火炎基部底 面から $20[\mathrm{~mm}]$ の火炎基部を対象とし, 軸・半径方向ともに $2[\mathrm{~mm}]$ ごとに測定した。熱電対の位置調整にはトラバース装 置を用いた。実験条件は Table.1に示す。

Table.1 Experimental condition

\begin{tabular}{|l|c|c|c|c|c|c|c|}
\hline & Do[mm & Di $[\mathrm{mm}]$ & $\mathrm{do}[\mathrm{mm}]$ & $\mathrm{di}[\mathrm{mm}]$ & $\mathrm{Nh}[\mathrm{mm}]$ & $\mathrm{A}\left[\mathrm{mm} \mathrm{m}^{2}\right]$ & $\mathrm{Dh}[\mathrm{mm}]$ \\
\hline Nozle.1 & 8 & 6 & 5 & 3 & 10 & 8.6 & 1 \\
\hline Nozle. 2 & 10 & 8 & 5 & 3 & 10 & 30.6 & 3 \\
\hline Nozle. 3 & 13 & 11 & 5 & 3 & 10 & 75.4 & 6 \\
\hline Nozle.4 & 10 & 8 & 5 & 3 & 5 & 30.6 & 3 \\
\hline Nozle.5 & 10 & 8 & 5 & 3 & 15 & 30.6 & 3 \\
\hline \hline $\mathrm{Q}\left[\times 10^{-3} \mathrm{~m}^{3} / \mathrm{s}\right]$ & 0.1 & 0.2 & 0.3 & 0.4 & 0.5 & 0.6 & \\
\hline
\end{tabular}

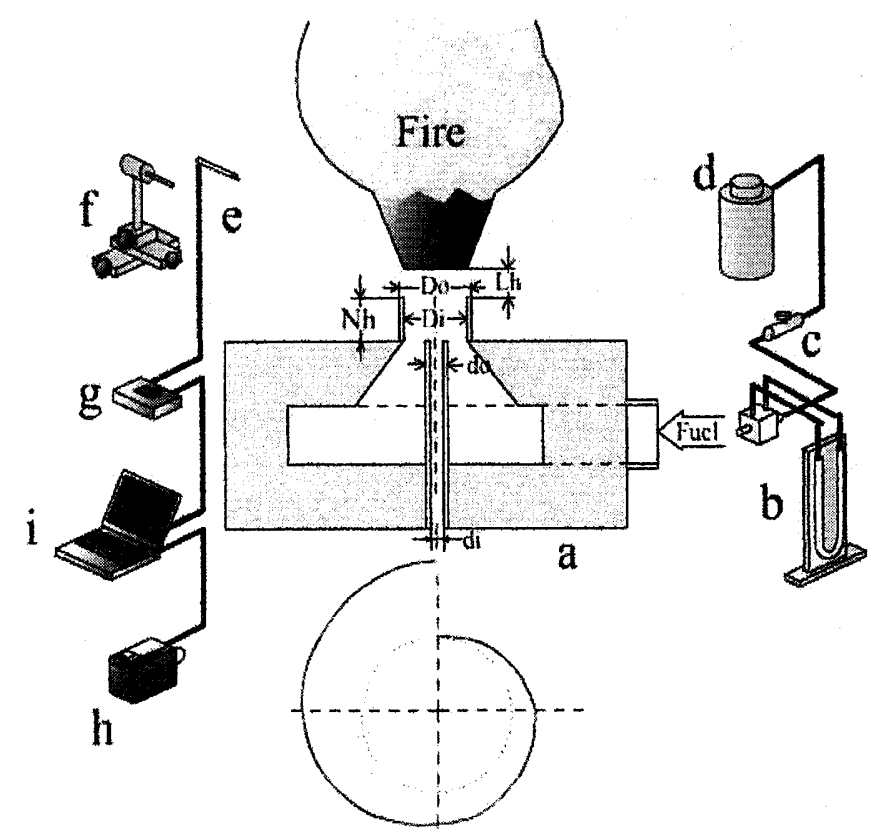

a:Burner,b:Orifice Manometer,c:Needle Valve,d:Propane Tank e:Thermocouple,f: Traverse,g:NR-1000,h:Degital Video Camera i:Personal Computer

Fig.1 Experimental apparatus 


\section{4. 実験結果と考察}

本研究の実験範囲で観察された火炎形状の特徽を述べるた めに代表的な火炎について考察する．Fig.2(a)は火炎全体を， Fig.2(b)はその火炎基部を撮影したものである.火炎全体とし ては螺旋形状をしている．火炎基部は逆円錐形で，青炎にな っており，予混合火炎のように燃料と酸化剂が理想的な割合 で混合し燃焼していると云える。火炎基部から下流の，青炎 から黄炎に変わる領域では火炎幅が急拡大している.

Fig.3 は同条件での火炎基部の温度分布であり，範囲は Fig.2(b)の赤枠(1)内にあたる. 半径方向ではノズルから中心に かけて $400^{\circ} \mathrm{C}$ 以下低温になっており，火炎が存在しないこ とがわかる．火炎の外側での反応が激しいことから，中心管 から誘引される空気より火炎外周の空気との混合が促進され ていると推測される.

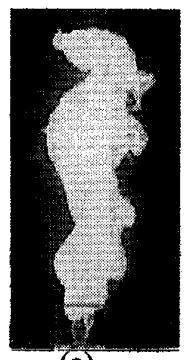

(a)

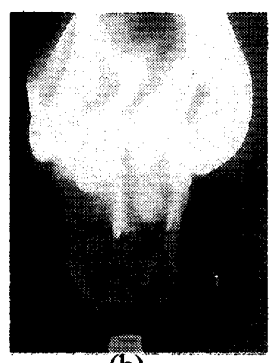

(b)
Fig.2 Flame image

$\left(\mathrm{Di}=10[\mathrm{~mm}], \mathrm{Nh}=10[\mathrm{~mm}], \mathrm{Q}=0.2 \times 10^{-3}\left[\mathrm{~m}^{3} / \mathrm{s}\right]\right)$

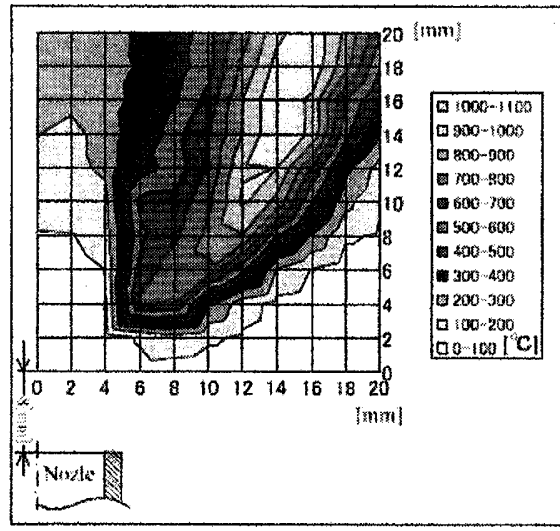

Fig.3 Temperature distribution

Fig.4 は火炎全長 Fh に対するレイノルズ数の影響を示して いる. Fig.4(a)は, ノズル外管の径が異なるバーナーと旋回を かけない従来のブラストバーナ一の火炎である. st は旋回流 のない従来のブラストバーナーのものである. Fig.4(a)から， 旋回のある場合 Di が大きいものほど火炎全長が短くなって いることと，旋回をかけることで火炎全長が約 $1 / 2$ 以下にな っていることがわかる.Fig.4(b)は絞り部からのノズル長さ $\mathrm{Nh}$ が異なるバーナーの火炎である．Nh が長い程火炎全長が 短くなる傾向がみられるが，レイノルズ数が小さいところで は $\mathrm{Nh}=15[\mathrm{~mm}]$ と $\mathrm{Nh}=10[\mathrm{~mm}]$ の火炎全長が逆転する。

Fig.5 は火炎の浮き上がり高さLh のレイノルズ数に対する 変化を表す. Fig.5(a)は Di が異なるバーナーと従来のブラス トバーナーの比較である．旋回をかけたバーナーでは， Re が大きくなるにつれ浮き上がり高さの増加が鈍く, Di が小さ い程浮き上がり高さが大きくなっている．従来のブラストバ 一ナーと旋回をかけたバーナーとの比較から，レイノルズ数 が小さい範囲では従来のブラストバーナ一の方が浮き上がり 高さは低くなっている. しかし，レイノルズ数の増加により 浮き上がり高さの増加も激しくなっている。このことから，
燃料を大量に燃焼させる必要のある高負荷燃焼での保炎性は, 旋回をかけた本研究のバーナーが優れていると言える.

Fig.5(b)は浮き上がり高さ Lh に対するノズル長さ Nh の影 響を表す，浮き上がり高さはノズル長さが短い程低くなる傾 向はみられる．また， $\mathrm{Nh}=15[\mathrm{~mm}]$ では $\mathrm{Re}=230$ まで火炎がノ ズルに付着する。

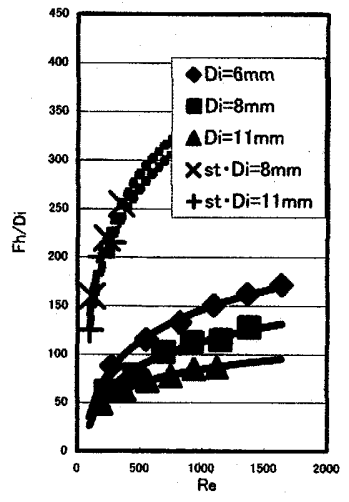

(a) $\mathrm{Di}=6,8,11[\mathrm{~mm}]$

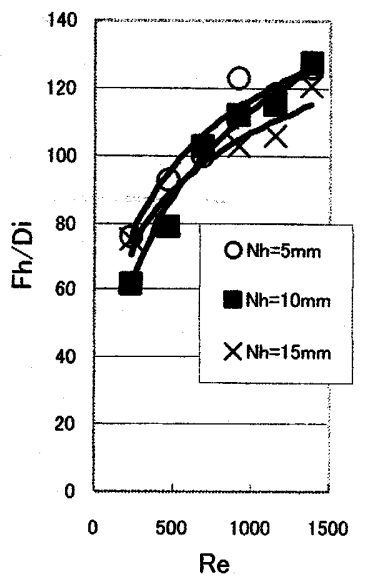

(b) $\mathrm{Nh}=5,10,15[\mathrm{~mm}]$
Fig.4 Flame height

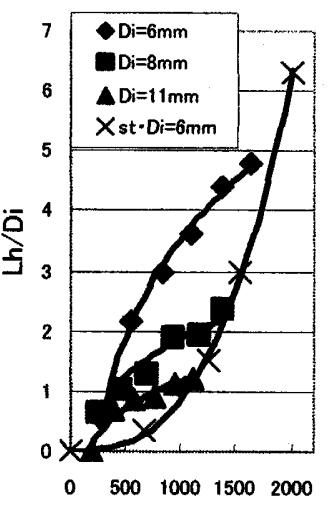

$\mathrm{Re}$ (b) $\mathrm{Nh}=5,10,15[\mathrm{~mm}]$

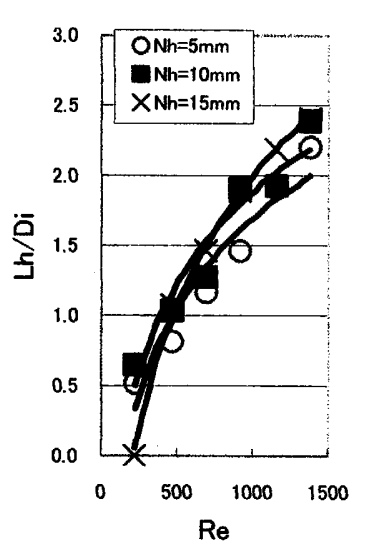

(a) $\mathrm{Di}=6,8,11[\mathrm{~mm}]$

Fig.5 Lift up height

\section{5. むすび}

環状断面から旋回燃料流を噴出する方式のバーナーの火炎 形状と温度分布を調べ, 従来のブラストバーナーと比較する ことから以下のことがわかった。

（1）旋回燃料流による火炎形状の特徵が明らかになった.

（2）燃料流に旋回をかけることで，火炎長を従来のブラス トバーナーの約 $50 \%$ 以下におさえることが出来る.

（3）燃料流に旋回をかけた場合，ノズル径が大きくなるほ どまたはノズル長さが小さいほど浮き上がり高さは小さく なる.

\section{文献}

（1）辻，機械の研究 燃焼現象論，(1976-1978)

(2) 松川，修士論文，(2001)

(3) 高木ら, 機論, 49-441, (1983), pp1078-1085 